Research Article

\title{
Chromosome studies in Orchidaceae from Argentina
}

\author{
Julio Rubén Daviña ${ }^{1}$, Mauro Grabiele ${ }^{1,2}$, Juan Carlos Cerutti ${ }^{1}$, Diego Hernán Hojsgaard ${ }^{1,3}$,
} Rubén Dario Almada ${ }^{1,4}$, Irma Stella Insaurralde ${ }^{1}$ and Ana Isabel Honfi ${ }^{1}$

${ }^{1}$ Programa de Estudios Florísticos y Genética Vegetal, Universidad Nacional de Misiones, Posadas, Argentina.

${ }^{2}$ Instituto Multidisciplinario de Biología Vegetal, Universidad Nacional de Córdoba, Córdoba, Argentina.

${ }^{3}$ Instituto de Botánica del Nordeste, Universidad Nacional del Nordeste, Corrientes, Argentina.

${ }^{4}$ Instituto de Biología Vegetal y Biotecnología, Universidad de Talca, Talca, Chile.

\begin{abstract}
The center of diversity of Argentinean orchids is in the northeast region of the country. Chromosome numbers and karyotype features of 43 species belonging to 28 genera are presented here. Five chromosome records are the first ones at the genus level; these taxa are Aspidogyne kuckzinskii $(2 n=42)$, Eurystyles actinosophila $(2 n=56)$, Skeptrostachys paraguayensis $(2 n=46)$, Stigmatosema polyaden $(2 n=40)$ and Zygostates alleniana $(2 n=54)$. In addition, a chromosome number is presented for the first time for 15 species: Corymborkis flava $(2 n=56)$, Cyclopogon callophyllus $(2 n=28)$, C. oliganthus $(2 n=64)$, Cyrtopodium hatschbachii $(2 n=46)$, C. palmifrons $(2 n=46)$, Galeandra beyrichii $(2 n=54)$, Habenaria bractescens $(2 n=44)$, Oncidium edwallii $(2 n=42), 0$. fimbriatum $(2 n=56)$, O. pubes $(2 n=84)$, O. riograndense $(2 n=56)$, Pelexia ekmanii $(2 n=46), P$. lindmanii $(2 n=46)$ and $W a r r e a$ warreana $(2 n=48)$. For Oncidium longicornu $(2 n=42)$, O. divaricatum $(2 n=56)$ and Sarcoglottis fasciculata $(2 n=46+1 B ?, 46+3 B ?)$, a new cytotype was found. Chromosome data support phylogenetic relationships proposed by previous cytological, morphologic and molecular analyses, and in all the cases cover some gaps in the South American literature on orchid chromosomes.
\end{abstract}

Key words: chromosome number, karyotype features, polyploidy, karyology, orchids, South America.

Received: November 6, 2008; Accepted: June 9, 2009.

\section{Introduction}

Orchidaceae Juss. is one of the largest families in the plant kingdom, distributed throughout the tropical and subtropical areas of both hemispheres (Correa, 1955). The family comprises around 850 genera and 20000 species, and nearly $75 \%$ of them are epiphytes (Dressler, 1993; Johnson, 2001). In Argentina, this family comprises around 74 genera and c. 280 species (Johnson, 1992; Correa, 1996) distributed throughout the country. Numerous orchids are part of the northeast Argentinean flora, particularly that of the provinces of Misiones (154 species), Corrientes (76), and Chaco (34) (Correa, 1996; Zuloaga et al., 1999; Insaurralde and Radins, 2007), and most of them have ornamental value.

Cytogenetic studies on Orchidaceae are few, disperse and incomplete. It is estimated that so far no more than about $10 \%$ of all species were chromosomally analyzed, therefore the chromosome evolution in this family remains

Send Correspondence to Julio Rubén Daviña. Programa de Estudios Florísticos y Genética Vegetal (PEFyGV), Universidad Nacional de Misiones, Rivadavia 2370 (3300) Posadas, Argentina. E-mail: julio@ invs.unam.edu.ar; juliordavina@gmail.com. in debate. The chromosome numbers vary from $2 n=10$ to $2 n=240$ and high numbers are common, the most frequent being $n=19$ or 20 (Jones, 1974). Regarding chromosome studies of South American orchids, the most important contributions were made by Blumenschein (Blumenschein A, PhD Thesis, University of São Paulo, Piracicaba, 1957; Blumenschein, 1960), Martínez (1981, 1985), Dematteis and Daviña (1999) and Felix and Guerra (1998, 1999, 2000, $2005)$, but the data are still considered insufficient. The cytology of orchids has been considered in the past to have a great potential in studies of taxonomic affinities and evolutionary bonds (Jones, 1974), and this is still true today, mainly if we take into account the phylogenetic gaps or misinterpretations of evolutionary trends. Moreover, in northeast Argentina, a great number of orchid populations are currently limited to remnants of the subtropical forest. Both epiphytes and terrestrial species grow in vegetation fragments, and their conservation is difficult due to changes in the habitat, patchy distribution and specific pollination strategies. For these reasons and as a first step towards characterization of the genetic variability of the species belonging to South American orchid genera, a cytological study was carried out. 


\section{Material and Methods}

Forty-three species of Orchidaceae from Argentina were chromosomally studied (Table 1). Samples were cultivated in the greenhouse of the Programa de Estudios Floristicos y Genetica Vegetal (FCEQyN - UNaM), and some of them have not flowered yet. Voucher specimens were deposited at the herbarium of the Universidad $\mathrm{Na}$ cional de Misiones (MNES). The taxonomic nomenclature adopted for the species was that of Govaerts et al. (2008). The results obtained are presented and discussed according to the classifications of Dressler (1993) and/or Szlachetko
(1995) at suprageneric levels. Mitotic studies were performed in root tips pretreated with saturated 1-bromonaphthalene for 2-3 hs at room temperature, fixed in absolute ethanol:glacial acetic acid $(3: 1)$ for $12 \mathrm{hs}$ at $4{ }^{\circ} \mathrm{C}$, and stained according to the Feulgen technique. The meristems were macerated in a drop of $2 \%$ aceto-orcein and then squashed. Permanent slides were made using euparal as a mounting medium. Slides were analyzed with a Leica DMLS optical photomicroscope, photographs were taken with Imagelink HQ 25 ASA Kodak film, and negatives were digitalized with a Genius ColorPage-HR8 scanner.

Table 1 - Chromosome numbers (2n) in Argentinean species of Orchidaceae.

\begin{tabular}{|c|c|c|c|}
\hline Taxon & $2 n$ & Locality and vouchers & $2 n$ - Previous references \\
\hline Aspidogyne kuczyynskii (Porsh) Garay ${ }^{2}$ & 42 & Ctes. Ituzaingó, Santa Tecla, Almada 151 & - \\
\hline Brassavola tuberculata Hook & 40 & Mnes. Capital, Posadas, Hojsgaard 228 & 40 - Afzelius (1943), Blumenschein (1960) \\
\hline $\begin{array}{l}\text { Campylocentrum neglectum (Rchb. f. \& } \\
\text { Warm.) Cogn. }\end{array}$ & 38 & $\begin{array}{l}\text { Chaco, San Fernando, Colonia } \\
\text { Benítez, Insaurralde } 676\end{array}$ & 38 - Dematteis and Daviña (1999) \\
\hline $\begin{array}{l}\text { Catasetum fimbriatum (C. Morren.) } \\
\text { Lindl. \& Paxton }\end{array}$ & 108 & Mnes. Capital, Posadas, Insaurralde 707 & $\begin{array}{l}108 \text { - Jones and Darker (1968), Dematteis and } \\
\text { Daviña (1999) }\end{array}$ \\
\hline Corymborkis flava (Sw.) Kuntze ${ }^{1}$ & 56 & $\begin{array}{l}\text { Mnes. San Pedro, P. P. Saltos del } \\
\text { Moconá, Daviña } 208\end{array}$ & - \\
\hline \multirow{2}{*}{$\begin{array}{l}\text { Cyclopogon callophyllus (Barb. Rodr.) } \\
\text { Barb. Rodr. }{ }^{1}\end{array}$} & 28 & Mnes. Capital, Nemesio Parma, Cerutti 74 & - \\
\hline & 28 & Ctes. Ituzaingó, Garapé, Cerutti 28 & - \\
\hline C. congestus (Vell.) Hoehne & 32 & $\begin{array}{l}\text { Mnes. Aristóbulo del Valle, Cuña } \\
\text { Pirú, Hojsgaard } 192\end{array}$ & \\
\hline \multirow[t]{2}{*}{ C. elatus (Sw.) Schltr. } & 28 & Mnes. Apóstoles, $\mathrm{A}^{\circ}$ Chimiray, Hojsgaard 341 & $\begin{array}{l}\text { 28, 30, } 45 \text { - Martínez (1981), Felix and Guerra } \\
(2005)\end{array}$ \\
\hline & 28 & Ctes. Capital, Insaurralde 708 & - \\
\hline \multirow{2}{*}{$\begin{array}{l}\text { C. oliganthus (Hoehne) Hoehne \& } \\
\text { Schltr. }{ }^{1}\end{array}$} & 64 & Mnes. Apóstoles, A ${ }^{\circ}$ Chimiray, Hojsgaard 339 & - \\
\hline & 64 & $\begin{array}{l}\text { Mnes. Capital, Posadas, } \text { A }^{\circ} \text { Zaimán, Cerutti } \\
71\end{array}$ & \\
\hline Cyrtopodium hatschbachii Pabst ${ }^{1}$ & 46 & $\begin{array}{l}\text { Mnes. Capital, Villa Lanús, A } \\
\text { Zaimán, Almada } 153\end{array}$ & - \\
\hline C. palmifrons Rchb. f. et Warm. ${ }^{1}$ & 46 & Mnes. Capital, Posadas, Hojsgaard 354 & - \\
\hline $\begin{array}{l}\text { Eurystyles actinosophila (Barb. Rodr.) } \\
\text { Schltr. }^{2}\end{array}$ & 56 & Mnes. Capital, Honfi 1358 & - \\
\hline Galeandra beyrichii Rchb. f. ${ }^{1}$ & 54 & Mnes. Capital, Garupá, Insaurralde 705 & - \\
\hline $\begin{array}{l}\text { Gomesa planifolia (Lindl.) Klotzsch ex } \\
\text { Rchb.f. }\end{array}$ & 56 & Mnes. San Pedro, Piñalito, Guillén 492 & - \\
\hline Habenaria bractescens Lindl. ${ }^{1}$ & 44 & Mnes. Capital, Garupá, Insaurralde 697 & - \\
\hline Leptotes unicolor Bar. Rodr. & 40 & Mnes. San Ignacio, Teyú Cuaré, Seijo 706 & 40 - Blumenschein (1960) \\
\hline \multirow[t]{2}{*}{ Mesadenella cuspidata (Lindl.) Garay } & 46 & Mnes. Capital, Garupá, Hojsgaard 349 & 46 - Martínez (1985) \\
\hline & 46 & Ctes. Ituzaingó, Garapé, Cerutti 68 & \\
\hline Miltonia flavescens (Lindl.) Lindl. & 60 & Mnes. Eldorado, Valle Hermoso, Honfi 1153 & $\begin{array}{l}60 \text { - Sinotô (1962, 1969), Charanasri et al. } \\
\text { (1973), Félix and Guerra (2000) }\end{array}$ \\
\hline
\end{tabular}




\section{Table 1 (cont.)}

\begin{tabular}{|c|c|c|c|}
\hline Taxon & $2 \mathrm{n}$ & Locality and vouchers & $2 n-$ Previous references \\
\hline \multirow[t]{2}{*}{ Oeceoclades maculata (Lindl.) Lindl. } & 56 & Mnes. San Ignacio, Dematteis 486 & 56 - Dematteis and Daviña (1999) \\
\hline & 56 & Mnes. Capital, Posadas, Daviña 613 & $\begin{array}{l}48, c .52,54,58 \text { - Guerra (1986), Felix and } \\
\text { Guerra }(2000)\end{array}$ \\
\hline Oncidium bifolium Sims & 108 & Mnes. Guaraní, Honfi 1359 & 108 - Dematteis and Daviña (1999) \\
\hline O. divaricatum Lindl. ${ }^{3}$ & 56 & $\begin{array}{l}\text { Mnes. Bernardo de Irigoyen, Pozo } \\
\text { Azul, Honfi } 1360\end{array}$ & 42 - Charanasri et al. (1973) \\
\hline O. edwallii Cogn. ${ }^{1}$ & 42 & $\begin{array}{l}\text { Mnes. Montecarlo, Puerto Rico, Insaurralde } \\
\text { w/n }\end{array}$ & - \\
\hline O. fimbriatum Lindl. ${ }^{1}$ & 56 & $\begin{array}{l}\text { Mnes. Bernardo de Irigoyen, Pozo } \\
\text { Azul, Honfi } 1363\end{array}$ & - \\
\hline O. longicornu Mutel $^{3}$ & 42 & Mnes. Iguazú, Puerto Iguazú, Daviña 615 & 56 - Dematteis and Daviña (1999) \\
\hline O. longipes Lindl. & 56 & Mnes. Iguazú, Puerto Iguazú, Daviña 616 & $\begin{array}{l}56 \text { - Blumenschein (1960), Dematteis and } \\
\text { Daviña (1999) }\end{array}$ \\
\hline O. pubes Lindl. ${ }^{1}$ & 84 & Mnes. Guaraní, Cabassi w/n & - \\
\hline O. riograndense Cogn. ${ }^{1}$ & 56 & $\begin{array}{l}\text { Mnes. Bernardo de Irigoyen, Pozo Azul, Hon- } \\
\text { fi } 1192\end{array}$ & - \\
\hline \multirow[t]{2}{*}{ Pelexia bonariensis (Lindl.) Schltr. } & 46 & Mnes. Capital, Nemesio Parma, Cerutti 29 & $\begin{array}{l}46 \text { - Martínez (1985), Dematteis and Daviña } \\
\text { (1999) }\end{array}$ \\
\hline & 46 & $\begin{array}{l}\text { Mnes. Candelaria, P. P. Cañadón de } \\
\text { Profundidad, Hojsgaard } 289\end{array}$ & \\
\hline P. ekmanii (Kraenzl) Schltr. ${ }^{1}$ & 46 & Mnes. Capital, Garupá, Radins 15 & - \\
\hline P. lindmanii Kraenzl ${ }^{1 .}$ & 46 & $\begin{array}{l}\text { Mnes. San Pedro, P. P. Saltos del } \\
\text { Moconá, Daviña } 123\end{array}$ & - \\
\hline Rodriguezia decora (Lem.) Rchb. f. & 42 & $\begin{array}{l}\text { Mnes. Bernardo de Irigoyen, Pozo } \\
\text { Azul, Honfi } 1362\end{array}$ & Sinoto (1962) \\
\hline Sacoila lanceolata (Aubl.) Garay & 46 & Mnes. Capital, Garupá, Radins 55 & $\begin{array}{l}46 \text { - Cocucci (1956), Martínez (1985), Felix } \\
\text { and Guerra (2005) }\end{array}$ \\
\hline \multirow[t]{3}{*}{ Sarcoglottis fasciculata (Vell.) Schltr. ${ }^{3}$} & $46,47,49$ & $\begin{array}{l}\text { Mnes. Capital, Nemesio Parma, Hojsgaard } \\
\text { 291B }\end{array}$ & 46 - Martínez (1985), Felix and Guerra (2005) \\
\hline & 46 & Mnes. Capital, Garupá, Insaurralde w/n & \\
\hline & 46 & Ctes. Ituzaingó, Garapé, Insaurralde w/n & \\
\hline \multirow[t]{2}{*}{ S. grandiflora (Hook.) Klotzsch } & 46 & Mnes. Capital, Nemesio Parma, Cerutti 56 & 46 - Martínez (1985) \\
\hline & 46 & Ctes. Ituzaingó, Garapé, Insaurralde w/n & \\
\hline S. ventricosa (Vell.) Hoehne & 46 & $\begin{array}{l}\text { Mnes. Montecarlo, Isla Caraguatay, Hojs- } \\
\text { gaard } 255\end{array}$ & 46 - Martínez (1985) \\
\hline $\begin{array}{l}\text { Skeptrostachys paraguayensis (Rchb. f.) } \\
\text { Garay }^{2}\end{array}$ & 46 & Mnes. Apóstoles, San José, Baumgratz 19 & - \\
\hline Sophronitis cernua Lindl. & 40 & Mnes. Capital, Posadas, Honfi 1361 & 40 - Blumenschein (1960) \\
\hline Stigmatosema polyaden (Vell.) Garay ${ }^{2}$ & 40 & Mnes. Apóstoles, San José, Hadad 18 & - \\
\hline $\begin{array}{l}\text { Trichocentrum pumilum (Lindl.) } \\
\text { M.W.Chase \& N.H.Williams }\end{array}$ & 30 & Mnes. Capital, Villa Lanús, Cerutti 73 & $\begin{array}{l}30 \text { - Dematteis (1997), Dematteis and Daviña } \\
\text { (1999), Felix and Guerra (2000) }\end{array}$ \\
\hline $\begin{array}{l}\text { Warrea warreana (Lodd. ex Lindl.) C. } \\
\text { Schweinf. }{ }^{1}\end{array}$ & 48 & $\begin{array}{l}\text { Mnes. San Pedro, P. P. Saltos del } \\
\text { Moconá, Insaurralde w/n }\end{array}$ & - \\
\hline Zygopetalum maxillare Lodd. & 48 & Mnes. Capital, Posadas, Daviña 614 & $\begin{array}{l}48 \text { - Blumenschein (1960), Tanaka and } \\
\text { Kamemoto (1984) }\end{array}$ \\
\hline Zygostates alleniana $\mathrm{Kraenzl}^{2}$ & 54 & $\begin{array}{l}\text { Mnes. Apostoles, } A^{\circ} \text { Chimiray, Hojsgaard } \\
343\end{array}$ & - \\
\hline
\end{tabular}

${ }^{1}$ First chromosome number for the species, ${ }^{2}$ First chromosome number for the genus, ${ }^{3}$ Taxa with chromosome numbers that differ from previously published reports.

Species are alphabetically grouped. All voucher specimens are deposited at MNES (Universidad Nacional de Misiones Herbarium). Mnes: Misiones, Ctes: Corrientes. 
Chromosome measurements were made using the MicroMeasure 3.3 computer program (Reeves, 2001).

\section{Results}

The 43 species of orchids chromosomally studied in this work belong to 28 genera distributed into five subfamilies: Epidendroideae (three species: Brassavola, Leptotes, Sophronitis), Orchidoideae (one; Habenaria), Spiranthoideae (17: Aspidogyne, Cyclopogon, Eltroplectris, Eurystyles, Mesadenella, Pelexia, Sacoila, Sarcoglottis, Skeptrostachys, Stigmatosema), Tropidoideae (one; Corymborkis) and Vandoideae (21: Campylocentrum, Catasetum, Cyrtopodium, Galeandra, Gomesa, Oeceoclades, Oncidium, Miltonia, Rodriguezia, Trichocentrum, Warrea, Zygopetalum, Zygostates) and are summarized in Table 1. Selected photomicrographs of the chromosomes of some species are shown in Figures 1, 2 and 3 .

Five chromosome counts are first records at genus level; these species are: Aspidogyne kuckzinskii $(2 n=42)$ (Figure $1 \mathrm{G})$, Eurystyles actinosophila $(2 n=56)$ (Figure $1 \mathrm{H})$, Skeptrostachys paraguayensis $(2 n=46)($ Figure $1 \mathrm{~J})$, Stigmatosema polyaden $(2 n=40)$ (Figure 1I) and
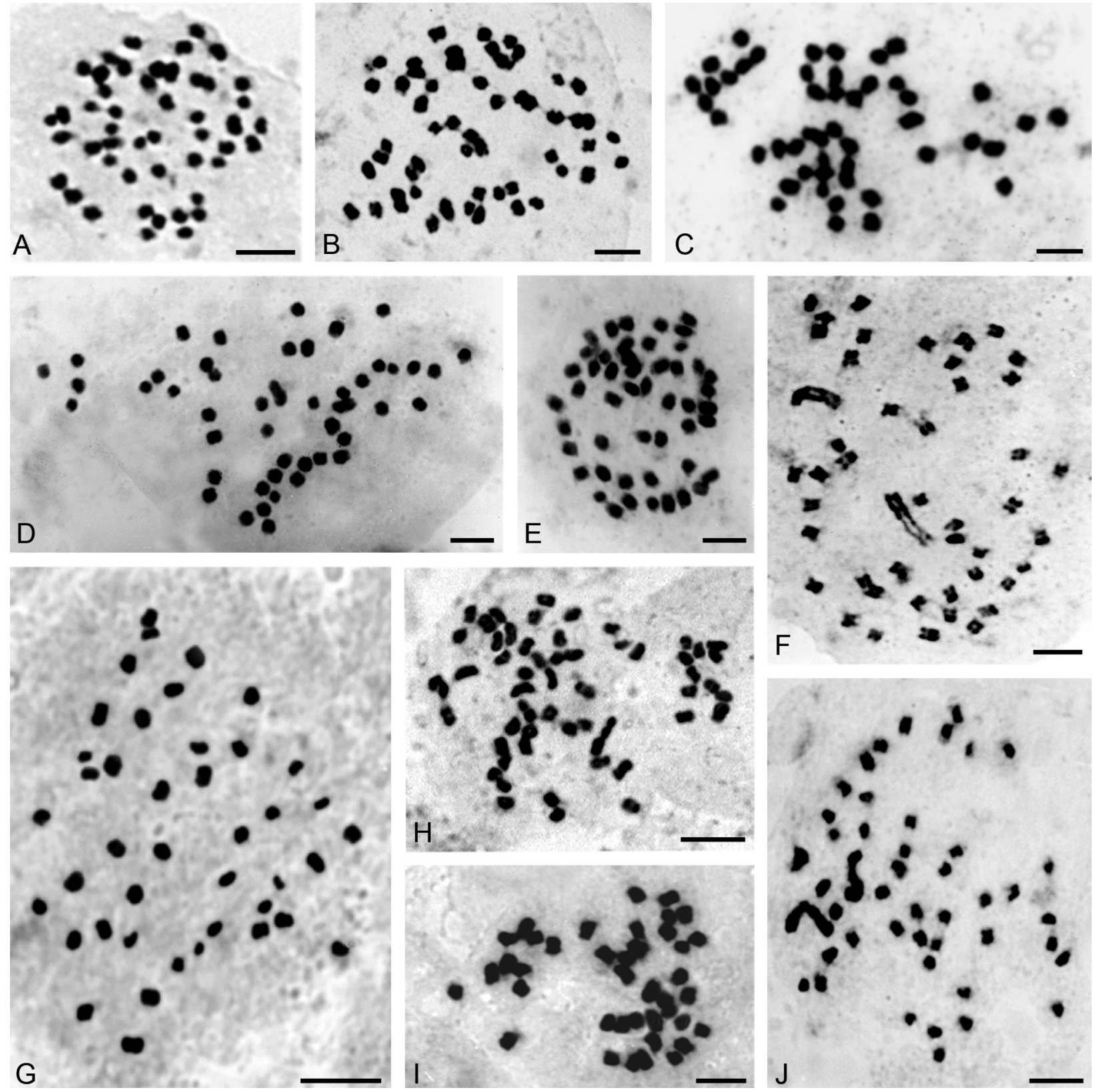

Figure 1 - Somatic chromosomes of: (A) Pelexia lindmanii $(2 n=46)$, (B) P. ekmanii $(2 n=46)$, (C) Sarcoglottis fasciculata (2n=46), (D) S. fasciculata $(2 n=47)$, (E) S. fasciculata (2n=49), (F) Mesadenella cuspidata $(2 n=46),(\mathrm{G})$ Aspidogyne kuczynskii $(2 n=42),(\mathrm{H})$ Eurystyles actinosophila $(2 n=56)$, (I) Stigmatosema polyaden $(2 n=40)$, and (J) Skeptrostachys paraguayensis $(2 n=46)$. Scale bars $=5 \mu \mathrm{m}$. 
Zygostates alleniana $(2 n=54)$ (Figure $2 \mathrm{~F})$. Fifteen additional species had not yet been studied chromosomally, so this is the first record too: Corymborkis flava $(2 n=56)$ (Figure $2 \mathrm{H})$, Cyclopogon callophyllus $(2 n=28), C$. oliganthus $(2 n=64)$, Cyrtopodium hatschbachii $(2 n=46)$ (Figure 2D), C. palmifrons $(2 n=46)$, Galeandra beyrichii $(2 n=54)$ (Figure $2 \mathrm{G})$, Gomesa planifolia $(2 n=56)$ (Figure
3I), Habenaria bractescens $(2 n=44)$ (Figure 2I), Oncidium fimbriatum $(2 n=56)$ (Figure $3 \mathrm{E})$, O. pubes $(2 n=84)$ (Figure 3G), O. edwallii $(2 n=42)$ (Figure 3H), $O$. riograndense $(2 n=56)$, Pelexia lindmanii $(2 n=46)$ (Figure 1A), P. ekmanii $(2 n=46)$ (Figure 1B), and Warrea warreana $(2 n=48)$ (Figure 2A). For Oncidium longicornu $(2 n=42)$ (Figure 3D), O. divaricatum $(2 n=56)$ (Figure 3F)
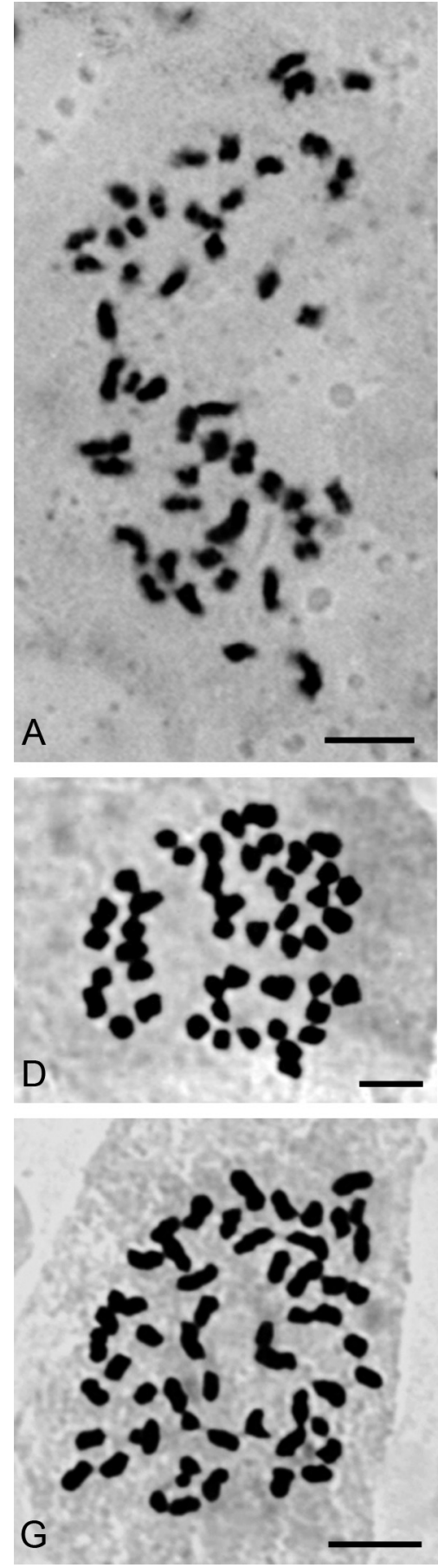
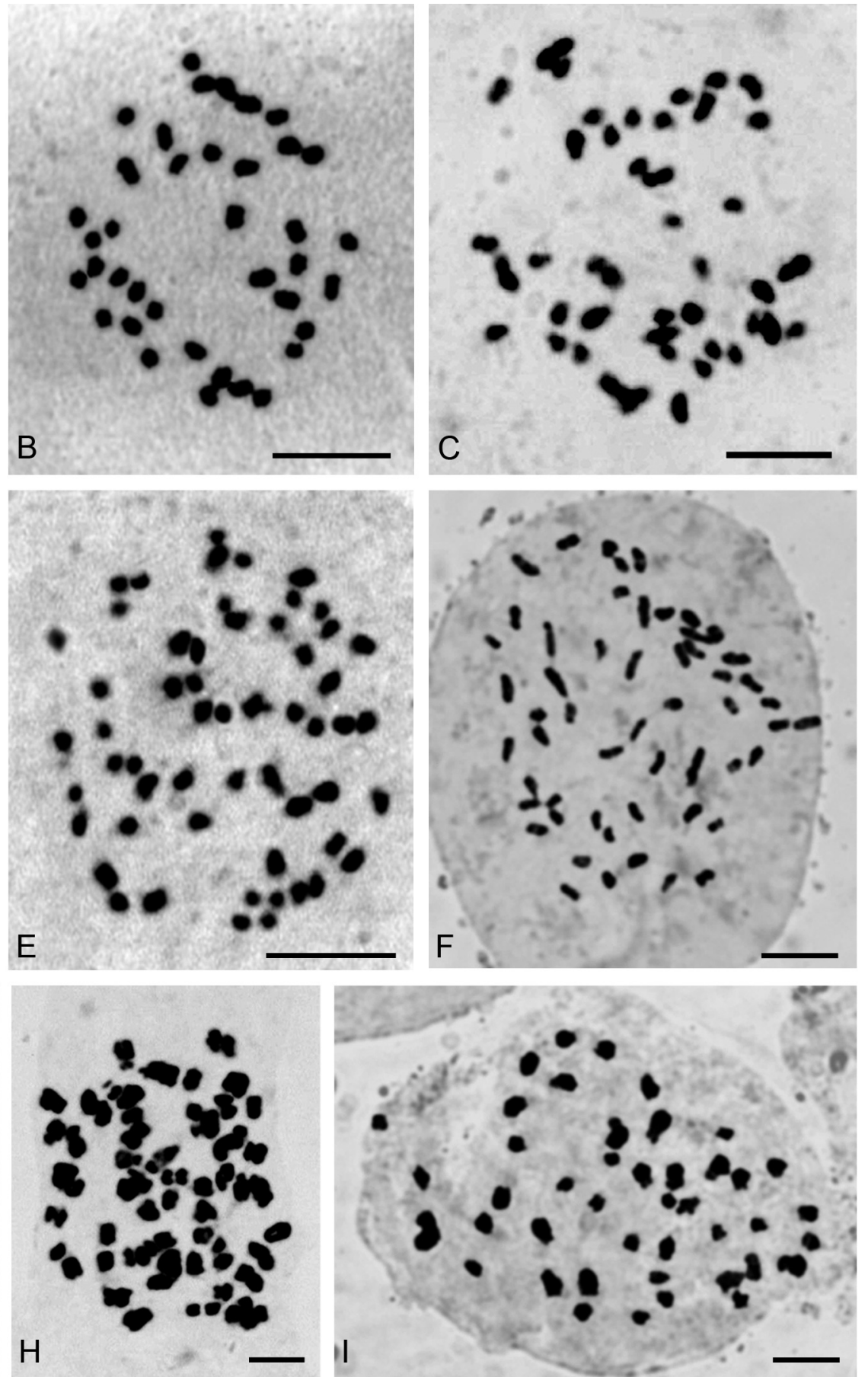

Figure 2 - Somatic chromosomes of: (A) Warrea warreana $(2 n=48)$, (B) Campylocentrum neglectum $(2 n=38)$, (C) Rodriguezia decora $(2 n=42)$, (D) Cyrtopodium hatschbachii $(2 n=46)$, (E), Oeceoclades maculata $(2 n=56)$, (F) Zygostates alleniana $(2 n=54)$, (G) Galeandra beyrichii $(2 n=54)$, $(\mathrm{H})$, Corymborkis flava $(2 n=56)$, and (I) Habenaria bractescens $(2 n=44)$. Scale bars $=5 \mu \mathrm{m}$. 

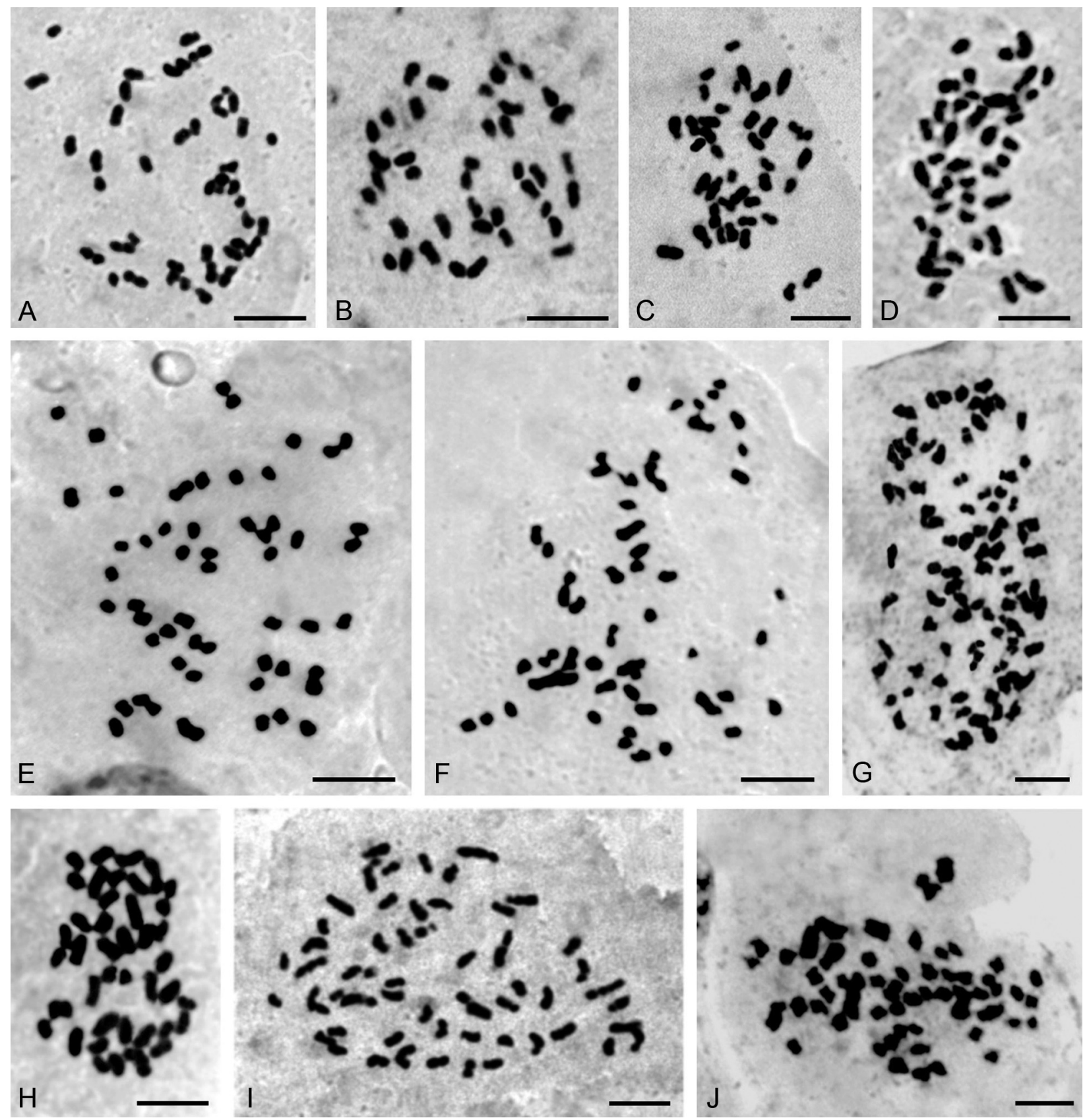

Figure 3 - Somatic chromosomes of: (A) Brassavola tuberculata $(2 n=40)$, (B) Leptotes unicolor $(2 n=40)$, (C), Sophronitis cernua $(2 n=40)$, (D) Oncidium longicornu $(2 n=42)$, (E) O. fimbriatum $(2 n=56)$, (F) O.divaricatum $(2 n=56)$, (G) O. pubes $(2 n=84),(\mathrm{H}) O$. edwalli $(2 n=42)$, (I) Gomesa planifolia $(2 n=56)$, and $(\mathrm{J})$ Miltonia flavescens $(2 n=60)$. Scale bars $=5 \mu \mathrm{m}$.

and Sarcoglottis fasciculata $(2 n=46,46+1 \mathrm{~B} ?, 46+3 \mathrm{~B}$ ?), new cytotypes were found (Figure 1C,D,E). Many results (20) are in accordance with previous chromosome reports, but some of them (7) are first records for Argentinean orchid populations, like Brassavola tuberculata $(2 n=40)$ (Figure 3A), Campylocentrum neglectum $(2 n=38)$ (Figure 2B), Leptotes unicolor $(2 n=40)$ (Figure 3B), Miltonia flavescens $(2 n=60)$ (Figure $3 \mathrm{~J})$, Rodriguezia decora $(2 n=42)$ (Figure 2C), Sophronitis cernua $(2 n=40)$ (Figure $3 \mathrm{C})$, and Zygopetalum maxillare $(2 n=48)$. Furthermore, we also found a $2 n=56$ cytotype in Oeceoclades maculata populations, which differs from previous counts performed in Brazilian materials (Figure 2E).

In most of the analized taxa, the karyotype was found to be of the bimodal type. Bimodality is present to varying degrees, as evidenced by the short/large chromosome ratio (S/L). Some Epidendroideae species showed small chromosomes, ranging from 0.5 to $2.5 \mu \mathrm{m}(\mathrm{S} / \mathrm{L}=0.20)$. The chromosomes of Habenaria (Orchidoideae) were small, ranging from 1 to $3 \mu \mathrm{m}(\mathrm{S} / \mathrm{L}=0.33)$, whereas those of 
Corymborkis (Tropidoideae) were of median size, ranging from 1 to $4 \mu \mathrm{m}(\mathrm{S} / \mathrm{L}=0.25)$. In Vandoideae, most of the species showed small chromosomes, ranging from 0.5 to $2.5 \mu \mathrm{m}(\mathrm{S} / \mathrm{L}=0.20)$, except for Gomesa (small to median, 0.5 to $4 \mu \mathrm{m} ; \mathrm{S} / \mathrm{L}=0.13$ ) and Warrea and Zygopetalum (median size, 0.5 to $3 \mu \mathrm{m} ; \mathrm{S} / \mathrm{L}=0.17)$. The Spiranthoideae species showed the widest variation regarding both chromosome size and interchromosomal asymmetry. Cyclopogon has median-size chromosomes ( 1.75 to $3.5 \mu \mathrm{m} ; \mathrm{S} / \mathrm{L}=0.50$ ), just as Pelexia and Sarcoglottis ( 1.4 to $3.7 \mu \mathrm{m} ; \mathrm{S} / \mathrm{L}=0.38$ ), whereas Eltroplectris schlechteriana $(2 n=26)$, Mesadenella cuspidata $(2 n=46$, Figure 1F), Sacoila lanceolata and Skeptrostachys paraguayensis present small to large chromosomes ( 1.25 to $5 \mu \mathrm{m} ; \mathrm{S} / \mathrm{L}=0.25$ ), with one chromosome pair that is twice as large as the chromosome mean and carries a macrosatellite on the short arm. The other genera exhibit small chromosomes, as follows: Aspidogyne ( 0.5 to $2 \mu \mathrm{m} ; \mathrm{S} / \mathrm{L}=0.25$ ), Eurystyles $(0.5$ to $2.5 \mu \mathrm{m}$; $\mathrm{S} / \mathrm{L}=0.20)$ and Stigmatosema ( 1 to $2.5 \mu \mathrm{m} ; \mathrm{S} / \mathrm{L}=0.40$ ).

\section{Discussion}

A wide diversity in chromosome numbers and karyotype features was found among the species of orchids that inhabit the northeast region of Argentina. In order to clarify any possible relationships among taxa, the results obtained are discussed, first circumscribed to each subfamily as starting point and then as a whole.

Epidendroideae is a large subfamily that comprises about 220 genera and the most common chromosome numbers are $2 n=28,30,32,34,36,38,40,42,46,48,50$ (Szlachetko, 1995). From this clade, we analyzed three species, Brassavola tuberculata, Leptotes unicolor and Sophronitis cernua, and our chromosome count $(2 n=40)$ agrees with previous reports (Afzelius, 1943; Blumenschein, 1960). These three genera belong to the subtribe Laeliinae (tribe Epidendreae) that comprises around 31 genera and 1466 species (Dressler, 1993; Szlachetko, 1995). The chromosome number in the neotropical orchid subtribe Laeliinae varies from $2 n=24$ to $2 n=56$, but is most commonly $2 n=40$ (Tanaka and Kamemoto, 1984). Our chromosome records, along with previous ones obtained for these genera (Afzelius, 1943; Kamemoto, 1950; Mehlquist, 1953; Blumenschein, 1960; Chardard, 1963), support the hypothesis that $2 n=40$ is the most common number for Laeliinae (Cameron et al., 1999; Dematteis and Daviña, 1999), for which the basic chromosome number could be a multiple of $x=10$.

The Orchidoideae subfamily cromprises around 78 genera, including Habenaria, and the most common chromosome numbers are $2 n=30,32,36,38,40,42,44,46,48$ (Szlachetko, 1995). Habenaria (tribe Orchideae) is a cosmopolitan genus with around 600-800 terrestrial species, of which 21 occur in Argentina (Correa, 1996; Felix and Guerra, 1998; Johnson, 2001). The chromosome count found for $H$. bractescens $(2 n=44)$, which is the first one for this species, is present in only $7 \%$ of the chromosomally analyzed Habenaria species, as this genus shows a wide diversity of cytotypes (35), ranging from $2 n=28$ (Tanaka, 1971) to 168 (Mehra and Sehgal, 1974), and the most common are $n=21$ and $2 n=42$ (Felix and Guerra, 1998).

Subfamily Spiranthoideae encompasses about 95 genera and 1140 species, predominantly terrestrial (Salazar et al., 2003), with $2 n=24,26,28,30,32,36,44$, and 46 as the most common chromosome numbers (Szlachetko, 1995). However, Cameron et al. (1999) did not recognize this clade as a separate subfamily and included it within Orchidoideae. We analyzed 17 species of 10 genera and found a wide diversity of chromosome numbers, i.e., $2 n=26,28,32,40,42,46,56,64$. This is the first time chromosome counts of Aspidogyne, Eurystyles and Stigmatosema species were made, but more studies are needed on these neglected genera. In natural populations of Aspidogyne kuczynskii, we observed polymorphism for the color of the leaves among different plants, but all phenotypes presented the same chromosome number.

The type of karyotype bimodality observed in Sacoila, Skeptrostachys, Mesadenella and Eltroplectris, with a chromosome pair twice as large as the mean chromosome size and carrying a macrosatellite on the short arm, along with previous cytogenetical data (Cocucci, 1956; Martínez, 1985; Dematteis and Daviña, 1999; Felix and Guerra, 2005), support their inclusion in a separate clade (subtribe Stenorrynchidinae sensu Szlachetko, 1995; Stenorrhynchos clade sensu Salazar et al., 2003). On the other hand, Pelexia bonariensis, P. ekmanii, P. lindmanii, Sarcoglottis fasciculata, $S$. grandiflora and $S$. ventricosa also share the chromosome number $(2 n=46)$ and the general karyotype features, which, together with previous cytogenetic data for those genera (Martínez, 1985; Dematteis and Daviña, 1999; Felix and Guerra, 2005), reinforces the proposal incorporating Pelexia and Sarcoglottis into the same clade (Dressler, 1993; Szlachetko, 1995; Salazar et al., 2003). Moreover, in S. fasciculata we found $2 n=46,47$ and 49 in the same plant. This variation in the somatic chromosome number may be due to the presence of B chromosomes with mitotic instability, as reported in several angiosperms (Jones and Rees, 1982), or aneusomaty.

The four Cyclopogon species analyzed here showed $2 n=28$ (C. callophyllus, and C. elatus), 32 (C. congestus) and 64 (C. oliganthus), representing new records for the first and the latter species. Cyclopogon is a taxonomically complex genus, as evidenced by morphological and molecular data (Dressler, 1993; Szlachetko, 1995; Salazar et al., 2003). In addition, it displays a wide diversity of chromosome numbers and ploidy levels, $n=14,16$ and $2 n=28,30$, 32, 36, 45, 64 (Martínez, 1981, 1985; Tanaka and Maekawa, 1983; Felix and Guerra, 2005; this work). For these reasons, detailed cytogenetical analyses to circumscribe this taxon are needed. 
Tropidoideae is a small subfamily that comprises three genera including Corymborkis (tribe Tropideae) (Szlachetko, 1995). Cameron et al. (1999), however, did not support this clade as a separate subfamily, but as a tribe of Epidendroideae. The chromosome count for Corymborkis flava $(2 n=56)$ reported here is the first one for this species. Only other two chromosome counts were made in this genus $(2 n=40,58)$, for $C$. veratrifolia, by Pancho (1965) and Ono and Masuda (1981), respectively.

The Vandoideae subfamily comprises around 347 genera distributed into 12 tribes, forming a monophyletic group with $2 n=38,40,42,46,48,50,52,54,56$ as the most common chromosome numbers (Szlachetko, 1995). Again, Cameron et al. (1999) did not recognize this clade as a separate subfamily and included it within Epidendroideae. We analyzed 21 species of 13 genera and found a wide diversity of chromosome numbers ranging from $2 n=30$ to 108 .

Among other genera, the tribe Cymbidieae encompasses Cyrtopodium, Galeandra and Oeceoclades (Dressler, 1993; Szlachetko, 1995). For Cyrtopodium, only 10 species had their chromosomes previously counted, showing $n=22$ and $2 n=46,92$ (Aoyama, 1989; Felix and Guerra, 2000). Cyrtopodium hatschbachii and $C$. palmifrons presented $2 n=46$, which, combined with the 23II observed at diakinesis in the former species (unpublished data), allows us to propose a basic chromosome number of $x=23$ for this genus, although it might be a derived number. For Galeandra, there are only two previous chromosome reports concerning $G$. baueri and $G$. devoniana, two epiphytic species with $2 n=56$ (Aoyama, $1989)$. Our count $(2 n=54)$ in $G$. beyrichii, a terrestrial species, suggests that there is probably more than one basic chromosome number in this genus. As in Galeandra, Felix and Guerra (2000) report different chromosome numbers for Brazilian Cyrtopodium and Oncidium orchids with different habitats. Genus Oeceoclades comprises about 39 species distributed over Africa, and O. maculata is the only one that also lives in America (Govaerts et al., 2008). In Brazilian O. maculata populations, $2 n=48$, c.52, 54, 58 cytotypes were found (Guerra, 1986; Felix and Guerra, 2000). However, for Argentinean populations, we consistently observed a $2 n=56$ cytotype, in agreement with our previous work (Dematteis and Daviña, 1999). Our results regarding $O$. maculata agree with the proposal of the primary basic number $x_{1}=7$ for Cymbidieae, presented by Felix and Guerra (2000), so this species could be considered an octoploid.

Catasetum (tribe Catasetinae) is an American genus with 163 species (Govaerts et al., 2008), and $2 n=54$ is the most common chromosome number. In $C$. fimbriatum, we observed $2 n=108$. The available chromosome data for the genus (Jones and Darker, 1968; Dematteis and Daviña, 1999; Felix and Guerra, 2000) suggest a polyploid series, probably based on $\mathrm{x}=6$. Cameron et al. (1999) and Cameron (2004) support the idea that genus Galeandra
(Cymbidieae) is closer to Catasetum than to Cyrtopodium (Cymbidieae), and our chromosome counts reinforce their proposal.

Warrea warreana and Zygopetalum maxillare presented $2 n=48$ median-size chromosomes. Both genera are included in the same clade, tribe Maxillarieae, according to Dressler (1993), or Zygopetaleae sensu Szlachetko (1995). Our cytogenetic data, along with previous chromosome number reports for both genera (Blumenschein, 1960; Tanaka and Kamemoto, 1984; Aoyama, 1989; Aoyama et al., 1994), support the idea of their inclusion in the same clade and reinforce the hypothesis of $x=24$ or 26 in this group (Felix and Guerra, 2000).

Campylocentrum neglectum (tribe Vandeae) showed a $2 n=38$, and this is the first count for natural populations from Argentina. The chromosome number agrees with that from Paraguay reported by Dematteis and Daviña (1999). No other Campylocentrum species were chromosomally analyzed so far, although 64 tropical and subtropical American species of this genus were described.

Zygostates alleniana (tribe Maxillarieae sensu Dressler, 1993; tribe Ornithocephaleae sensu Szlachetko, 1995 ) presented $2 n=54$ small chromosomes, and this is the first count for the genus.

The subtribe Oncidiinae is taxonomically complex (Dressler, 1993; Szlachetko, 1995; Felix and Guerra, 2000; Chase et al., 2005). Both Dressler (1993) and Szlachetko (1995) recognize this clade, but the former included it within the tribe Maxillarieae of the Cymbidioid phylad, and the latter within the Vandoideae tribe Oncidieae. The variability in chromosome numbers is a representative feature of Oncidiinae, showing the widest range of variation within orchids, from $2 n=10$ to 168 , but $2 n=56,60$ and 42 are the most common within a polyploid series based on $x=7(\mathrm{Fe}-$ lix and Guerra, 2000). We analyzed species of Gomesa, Miltonia, Oncidium, Rodriguezia and Trichocentrum (subtribe Oncidiinae sensu Dressler, 1993; tribe Oncidieae sensu Szlachetko, 1995) and found $2 n=30,42,60,84,108$, emphasizing the proposal of $x=7$ for this clade made by Felix and Guerra (2000).

Oncidium is a large neotropical genus with showy epiphytic, litophytic and terrestrial species, and some of them can be misidentified when in vegetative state. This genus has been extensively studied, showing $2 n=56,42,28$ as the most common chromosome numbers (Felix and Guerra, 2000). All the Oncidium species analyzed here showed small chromosome size $(0.5$ to $3 \mu \mathrm{m})$ and presented $2 n=42,56$ as the most common numbers, with the exception of $O$. bifolium $(2 n=108)$ and $O$. pubes $(2 n=84)$. Cytotype $2 n=84$ is present in at least six species (Tanaka and Kamemoto, 1984; Felix and Guerra, 2000) that could be considered 12-ploid, whereas cytotype $2 n=108$ could be considered a 16-ploid derived from $2 n=112$, both based on $x=7$. 
Trichocentrum pumilum showed $2 n=30$, which is in agreement with previous records (as Oncidium pumilum, Dematteis, 1997; Dematteis and Daviña, 1999; Felix and Guerra, 2000); cytological data sustain the exclusion of $O$. pumilum from genus Oncidium, in accordance with molecular data (Williams et al., 2001).

Rodriguezia decora was found to have $2 n=42$, and this is the first count for natural populations from Argentina. Sinotô (1962) previously reported the same number for Brazilian populations. Only eight species of Rodriguezia had their chromosomes counted, consistently showing $2 n=42$ (Felix and Guerra, 2000). The chromosome count $2 n=56$ is the first one for Gomesa planifolia. The chromosomes of this genus were nearly unknown, since only two other species were previously counted: $G$. recurva and G. crispa ( $2 n=56$; Sinotô, 1962, 1969; Charanasri et al., 1973; Tanaka and Kamemoto, 1984). Miltonia flavescens showed $2 n=60$, and this is the first count for natural populations from Argentina, coinciding with that of Sinotô $(1962,1969)$, Charanasri et al. (1973) and Félix and Guerra (2000). Eight Miltonia species had their chromosome counts reported, with $2 n=60$ and $2 n=56$, in that order, as the most common numbers, but $2 n=59,86$ were also found (Sinotô, 1962, 1969; Charanasri et al., 1973; Charanasri and Kamemoto, 1975). Felix and Guerra (2000) proposed that the Miltonia species which had their chromosomes counted are octoploids from $x=7$, and dysploidy is thought to explain the cytotype $2 n=60$.

At any stage of analysis, Orchidaceae is a complex taxon. Its large number of species, along with a wide variation at the morphological, ecological and cytological levels, have made it difficult to establish an accurate phylogenetic scenario using classical approaches. Therefore, different criteria for the classification of these orchids as a whole have been applied, such as those of Dressler (1993) and Szlachetko (1995) as the most recent analyses, resulting in different evolutionary pictures. Molecular analysis of the orchids as a whole (i.e., Cameron et al., 1999; Cameron, 2004; Chase et al.,2005) or of any of their larger clades (i.e., Cameron and Chase, 2000; Chase et al., 2005; Van den Berg et al., 2005) proved to aid the classical approaches, but differing at some point. Regarding the number of subfamilies comprised by Orchidaceae, several contradictions have arisen between classical and molecular analysis. Dressler (1993) and Szlachetko (1995) do not assign the genera to the same taxonomic intra-family categories, whereas Cameron et al. (1999) support five major monophyletic clades, delimiting some taxa sustained by the former authors (such as inclusion of Vandoideae and Tropidoideae into Epidendroideae and inclusion of Spiranthoideae into Orchidoideae). In addition, whatever the classification criterion, the wide diversity in chromosome number within each subfamily of Orchidaceae added to the few cytologic data available, make it difficult to discuss the taxo- nomic and molecular contradictions at this level based on cytogenetic findings, although the latter proved to be a powerful tool for solving doubts regarding lower taxonomic ranks (i.e., Martínez, 1985; Aoyama, 1989; Aoyama et al., 1994; Felix and Guerra, 1998, 2000, 2005; Luo, 2004; this work).

Our contribution, along with the literature data, reveal that Orchidoideae (sensu Cameron et al., 1999) is composed mainly of polyploid strains with $2 n=24,26,28,30$, $32,36,38,40,42,44,46,48,56,64$ as the most common chromosome numbers, while in Epidendroideae (sensu Cameron et al., 1999) the polyploids $2 n=28,30,32,34,36$, $38,40,42,46,48,50,52,54,56$ are predominant, although $2 n=60,84,108$ also occurr. According to Felix and Guerra $(2000,2005), x_{1}=7$ is the primary basic chromosome number for Orchidaceae, composed mostly by paleopolyploids, with the predominance of the series $n=7,14,21,28,42$ added to dysploidy at each level. The diversity in chromosome numbers and distribution of the orchids that inhabit the northeast region of Argentina analyzed here reinforces the proposal of these authors.

Regarding chromosome size and interchromosomal asymmetry, our results point out that in Epidendroideae (sensu Cameron et al., 1999) small chromosomes and definitely bimodal karyotypes predominate, with the exception of Corymborkis, of uncertain phylogenetic position, which has mostly median-size chromosomes. Furthermore, our results on Orchidoideae (sensu Cameron et al., 1999) reveal the presence of small, median and large chromosomes, and, with the exception of Cyclopogon and Stigmatosema, distinctly bimodal karyotypes, which is more evident in Eltroplectris, Mesadenella, Sacoila and Skeptrostachys. Particularly, the chromosome size and karyotype features of the species of the Orchidoideae tribe Cranichideae [Spiranthoideae sensu Dressler (1993) and Szlachetko (1995)] are good markers for supporting the current lower-rank clades proposed by the latter author.

The genetic variability of the orchids is also expressed by the diversity of their chromosome number and karyotype features. Progress in the cytogenetic research of orchids is essential to solve the still persisting contradictions between the results of morphologic and molecular analyses and to help developing an improved taxonomic approach.

\section{Acknowledgments}

The authors are grateful to professor Blas Roa ${ }^{\dagger}$ for his continuous encouragement and generous support and to Mr. Aurelio Schinini for his helpful comments and assistance with the bibliography. This work was funded in part by the PICT-O 36907 (SECyT-Argentina) project. "Deceased 7-09-2008. 


\section{References}

Aoyama M (1989) Karyomorphological studies in Cymbidium and its allied genera, Orchidaceae. Bull Hiroshima Bot Gard 11:1-121.

Aoyama M, Tanaka R and Hashimoto K (1994) Karyomorphological studies on some orchids belonging to subtribe Zygopetalinae. Kromosomo 73:2504-2524.

Afzelius K (1943) Zytologische Beobachtungen an einigen Orchidaceen. Bot Tidssk 37:266-276.

Blumenschein A (1960) Número de cromossomas de algumas espécies de orquídeas. Publ Cient Univ São Paulo 1:45-50 (Abstract in English).

Cameron KM, Chase MW, Whitten WM, Kores PJ, Jarrell DC, Albert VA, Yukawa T, Hills HG and Goldman DH (1999) A phylogenetic analysis of Orchidaceae: Evidence from rbcL nucleotide sequences. Am J Bot 86:208-224.

Cameron KM and Chase MW (2000) rDNA sequences of Orchidaceae confirm the subfamilial status and circumscription of Vanilloideae. In: Wilson KL and Morrison DA (eds) Monocots: Systematics and Evolution 18. CSIRO, Collingwood, pp 457-464.

Cameron KM (2004) Utility of plastid psaB gene sequences for investigating intrafamilial relationships within Orchidaceae. Mol Phyl Evol 31:1157-1180.

Charanasri U, Kamemoto H and Takeshita M (1973) Chromosome numbers in the genus Oncidium and some allied genera. Amer Orchid Soc Bull 42:518-524.

Charanasri U and Kamemoto H (1975) Additional chromosome numbers in Oncidium and allied genera. Am Orchid Soc Bull 44:686-691.

Chardard R (1963) Contribution a l'etude cyto-taxonomique des Orchidées. Rev Cytol Biol Veg 26:1-58.

Chase MW, Hanson L, Albert VA, Whitten WM and Williams NH (2005) Life history evolution and genome size in subtribe Oncidiinae (Orchidaceae). Ann Bot 95:191-199.

Cocucci A (1956) Cromosomas gaméticos de Stenorrhynchos australis Lindl. y Tradescantia radiata Clarke. Mus Bot Univ Nac Córd 2:781-783.

Correa MN (1955) Las orquídeas argentinas de la tribu Polychondreae Schlechter, subtribu Spiranthinae Pfitzer. Darwiniana 11:24-88

Correa MN (1996) Orchidaceae. In: Zuloaga FO and Morrone O (eds) Catálogo de las Plantas Vasculares de la República Argentina I. Pteridophyta, Gymnospermae y Angiospermae Monocotyledoneae. Monogr Missouri Bot Gard 60:242271.

Dematteis M (1997) The karyotypes of Oncidium morenoi and $O$. pumilum (Orchidaceae). Selbyana 18:186-187.

Dematteis M and Daviña JR (1999) Chromosome studies on some orchids from South America. Selbyana 20:235-238.

Dressler RL (1993) Phylogeny and Classification of the Orchid Family. Dioscorides Press, Portland, pp 314.

Felix LP and Guerra M (1998) Cytogenetic studies on species of Habenaria (Orchidoideae, Orchidaceae) occurring in the northeast of Brazil. Lindleyana 13:224-230.

Felix LP and Guerra M (1999) Chromosome analysis in Psygmorchis pusilla (L.) Dodson and Dressler: The smallest chromosome number known in Orchidaceae. Caryologia 52:165-168.
Felix LP and Guerra M (2000) Cytogenetics and cytotaxonomy of some Brazilian species of Cymbidioid orchids. Genet Mol Biol 23:1-27.

Felix LP and Guerra M (2005) Basic chromosome numbers of terrestrial orchids. Plant Syst Evol 254:131-148.

Guerra M (1986) Cytogenetic of angiosperms collected in the state of Pernambuco-I. Rev Bras Genet 9:21-40.

Insaurralde IS and Radins JA (2007) Misiones Orquídeas - Orchids. 1a ed. Buenos Aires Golden Company, Buenos Aires, 192 pp.

Johnson AE (1992) Listado tentativo de las orquídeas de la Argentina. (Abundancia - Distribución - Conservación). Boletín Técnico Fund Vida Silvestre Argentina 11:1-82.

Johnson AE (2001) Las Orquídeas del Parque Nacional Iguazú, LOLA, Buenos Aires, 296 pp.

Jones K (1974) Cytology and the study of orchids. In: Withner CL (ed) The Orchids: Scientific Studies. John Willey \& Sons, New York, pp 383-389.

Jones K and Darker MG (1968) The chromosomes of orchids III. Catasetinae Schltr. Kew Bull 22:421-427.

Jones RN and Rees H (1982) B chromosomes. Academic Press, London, $266 \mathrm{pp}$.

Kamemoto H (1950) Polyploidy in cattleyas. Bull Amer Orchid Soc 19:366-373.

Luo YB (2004) Cytological studies on some representative species of the tribe Orchideae (Orchidaceae) from China. Bot J Linn Soc 145:231-238.

Martínez AJ (1981) Notas citotaxonomicas sobre el género Cyclopogon Presl. Parodiana 1:139-148 (Abstract in English).

Martínez AJ (1985) The chromosomes of Orchids VIII. Spiranthinae and Cranichidinae Kew Bull 40:139-147.

Mehlquist GAL (1953) Polyploidy in orchid genera of commercial importance. Proc VII Internatl Bot Congr, pp 335.

Mehra RN and Sehgal RN (1974) In IOPB chromosome number report XLVI. Taxon 23:801-812.

Ono M and Masuda Y (1981) Chromosome numbers of some endemic species of the Benin Islands II. Ogasawara Res 4:124.

Pancho (1965) IOPB Chromosome number reports I-X (19641967). In: Fedorov A (ed) Chromosome Numbers of Flowering Plants. Leningrado. Reimpresión (1974), O. Koeltz Sci. Publ., Koenigstein, pp 1-928.

Reeves A (2001) MicroMeasure: A new computer program for the collection and analysis of cytogenetic data. Genome 44:439-443.

Salazar GA, Chase MW, Soto Arenas MA and Ingrouille M (2003) Phylogenetics of Cranichideae with emphasis on Spiranthinae (Orchidaceae, Orchidoideae): Evidence from plastid and nuclear DNA sequences. Am J Bot 90:777-795.

Sinotô Y (1962) Chromosome numbers in Oncidium alliance. Cytologia 27:306-313.

Sinotô Y (1969) Chromosomes in Oncidium and allied genera, I. Genus Oncidium. Kromosomo 76:2459-2473.

Szlachetko D (1995) Sistema Orchidalium. Frag Flor Geob 3(Suppl):1-152.

Tanaka R (1971) Types of interphase nuclei of Orchidaceae. Bot Mag 84:118-122.

Tanaka R and Maekawa F (1983) Observation of chromosome in some orchid species from Peru and Mexico. Ann Tsukuba Bot Gard 2:33-45. 
Tanaka R and Kamemoto H (1984) Chromosomes in orchids: Counting and numbers. In: Arditti J (ed) Orchid Biology: Reviews and Perspectives III. Cornell University Press, Ithaca, pp 324-410.

Van Den Berg C, Goldman DH, Freudenstein JV, Pridgeon AM, Cameron KM and Chase MK (2005) An overview of the phylogenetic relationships within Epidendroideae inferred from multiple DNA regions and recircumscription of Epidendreae and Arethuseae (Orchidaceae). Am J Bot 92:613624 .

Williams NH, Chase MW, Fulcher T and Whitten WM (2001) Molecular systematics of the Oncidiinae based on evidence from four DNA sequence regions: Expanded circumscriptions of Cyrtochilum, Erycina, Otoglossum, and
Trichocentrum and a new genus (Orchidaceae). Lindleyana 16:113-139.

Zuloaga FO, Morrone O and Rodríguez D (1999) Análisis de la biodiversidad de las plantas vasculares de la Argentina. Kurtziana 27:17-167.

\section{Internet Resources}

Govaerts R, Campacci MA, Holland Baptista D, Cribb P, George A, Kreuz K and Wood J (2008) World Checklist of Orchidaceae. The Board of Trustees of the Royal Botanic Gardens, Kew. http://www.kew.org/wcsp/ (July 20 2008).

$$
\text { Associate Editor: Marcelo Guerra }
$$

License information: This is an open-access article distributed under the terms of the Creative Commons Attribution License, which permits unrestricted use, distribution, and reproduction in any medium, provided the original work is properly cited. 